\title{
ARE FILIPINO HIGHER EDUCATION STUDENTS GETTING GLOBAL? AN EXPLORATORY STUDY OF A PRIVATE HIGHER EDUCATION IN BATANGAS CITY, PHILIPPINES
}

\author{
Remedios P. Magnaye, DBA \\ Lyceum of the Philippines University - Batangas \\ emiepascomagnaye626@yahoo.com
}

\begin{abstract}
This study evaluated the global competencies, skills and attitudes of the 247 first year students of the College of Business Administration in one of the private higher education institution in Batangas City, Philippines. An exploratory study through a self-constructed questionnaire assesses the manifestation of global competencies and the extent to which global skills and attitudes need improvements. Results revealed manifestations of global competencies including communicate effectively in English, wide understanding of the world, international understanding of their specialization and exhibit cross-cultural sensitivity and adaptability. Furthermore, the students affirmed the need for improvements in selfconfidence, creativity, patience, flexibility, courage, interest in continuous learning, perseverance, independence, resourcefulness and self-awareness. The statistical test of difference showed that the global competency differs based on age and not on sex nor program of study. Since the identified set of global skills and attitudes are too complex, the university needs to expose their students more in the different international students' development programs.
\end{abstract}

Keywords: global competence, global skills, higher education, Filipino students 


\section{Introduction}

Colleges and universities around the world are falling short of producing graduates equipped with global skills. For instance, according to Sparks (2015), U.S. millennials fall behind their peers in other countries in terms of global skills such as literacy, numeracy and computer-age problem-solving skills. The Philippines has a fair share of this dilemma. In the study conducted by Igarashi, Acosta, Hamanaka \& Rutkowski (2017), one-third of the employers are unable to find qualified candidates for the job due to lack of requisite skills. Interestingly, the missing skills are not academic or technical knowledge but non-cognitive or behavioural skills.

The 21st century challenges higher education institutions in producing global graduates equipped with necessary competencies, skills and attitudes. While global competence is critical, traditional teaching and learning approaches are still used in most educational institutions. For most of the colleges and universities in the Philippines, the struggle continuous with the limited technological resources. Furthermore, the inability to develop programs to allow global collaboration makes limited intercultural understanding and diversity. As English is the second language in the country, there are still issues with the use of the language among the college students.

As global students, they need to explore cultural differences. This allows them understand global complexities, challenges and issues necessary in making sound decisions outside their local comfort zones. The challenge for both the education institution and the students is to go beyond textbooks to connect and collaborate with peers and experts in the global scene. In this age and time, participation in an interconnected, complex and diverse society is no longer a luxury but a pressing necessity. Cognizant of the unique roles that schools, colleges and universities play in preparing the youth to participate in the global environment, administrators and educators alike are tasked to design tools and programs in nurturing the global skills, competence and attitudes of the young generation. However, Goodwin and Hein (2017) note that students need basic and applied knowledge, computational and creative thinking and hard and soft skills to succeed in a global world. 
As one of the pillars in producing global graduates, accreditation and international quality assurance is fast becoming a norm for private colleges and universities in the Philippines. For instance, one of the higher education institutions where the study was conducted put forward strong accreditation and international quality assurance system to produce competitive labor force in the different parts of the globe. The students are expected to possess and apply the qualities, characteristics and abilities to learn and engage himself with globally competitive issues. However, these are easier said than done.

The question remains as to the ability of the students acquire and develop global competencies throughout the course of their program. Thus, the current study was conceptualized to evaluate the global competencies, skills and attitudes of the business students. It specifically assessed the students' manifestation of global competencies and determined the extent of global skills and attitudes that need improvement. The study also tested the differences on the global competencies according to students' demographic profile. The study is imperative in the student development programs. These are the necessary inputs for administrators and educators alike in the continuous cultivation of academic excellence.

\section{Literature review}

The role of the education system in the development of future global leaders and business leaders is increasingly getting complex as the demand for global skills and competencies change overtime. At the basic level, 21st century competencies include knowledge, skills and attitudes enabling students to meet the demands of the changing workplace demographics. The complexity of global competencies provides a new educational landscape for most of the institutions. Thus, educational systems must have visionary educational response to the interconnected world of the 21 st century.

Global competence has no exact measure. For Boix-Mansilla \& Jackson (2011), it refers to the ability to understand and act on global issues. This requires students to investigate in a global perspective, communicate the ideas and take necessary actions. Meanwhile, World Savvy (n.d.) specifically refer it to the skills, values and behaviors that will enable people to succeed in a more diverse and interconnected environment. The Participate Learning (2017) has a more specific context referring to the soft skills and 
characteristics that students need to be globally competent. These soft skills and characteristics include appreciation of culture, evaluation of information, cross-cultural communication skills, perspective-taking skills, intelligent humility, divergent thinking and technological literacy. As clearly emphasized by Ravitz et al. (2012), anyone without global connections is not prepared in facing the world.

The issue on the global competence is getting a global attention. For instance, in a test conducted by Moriba \& Edwards (2015) on the global competence of the Agriculture students in the US found that less than one-fifth of the students achieved a "passing score" on the pre-course while less than one-third in the post-course knowledge test. Similarly, Tindowen, Bassig \& Caguranga (2017) found in their study that the students of the Alternative Learning System in Northern Philippines has low acquisition of the $21^{\text {st }}$ century skills. Findings finds creativity and innovation, ICT integration, collaboration and communication are low. However, the students have highest level acquisition of local connections skills.

Since lack of global competence persist in the different generations of students, the companies hiring workforce get the burden. Acosta, Igarashi, Olfindo \& Rutkowski (2017) reported that firms had difficulty finding workers with socioemotional skills from 2009 to 2015 in the Philippines. Two-thirds of the firms were challenged with applicants with no adequate work ethics and interpersonal and communication skills whereas one-half no technical skills proficiency. The socioemotional skills gap led companies to invest heavily in the staff training. In the Philippines, socioemotional skills are positively correlated with employment status and with higher levels of educational attainment. According to Brunello \& Wruuck (2019) the limited availability of skills poses an impediment to corporate investment. For example, in Europe the persistent skill gaps and mismatches come at economic and social costs.

In the QS Higher Education Report of 2018 on the Global Skills Gap of the $21^{\text {st }}$ century, the graduate skills gap has been identified as a global and widespread issue. The gaps exist across regions, countries and different types of firms. It was revealed that in the Asia-Pacific region, employers are least satisfied with creativity skills while higher satisfaction in ability to work in a team, interpersonal skills and technical skills. There is a 
clear disparity between the skills acquired by the students during their formal education and the skills required for work placement. If this impending challenge continues, how the colleges and universities fill the gap? Furthermore, if the skills gap within their own territories cannot be resolved, how can students be globally competitive?

The Organization for Economic Cooperation and Development (OECD) formulated the PISA Global Competence Framework. This highlights the skills assessed in the PISA 2018 which tests students' capabilities in four areas. According to OECD (2018), global competence is a multidimensional capacity enabling individuals to assess local, global and intercultural issues.

\section{Figure 1}

The OECD PISA dimensions of global competence

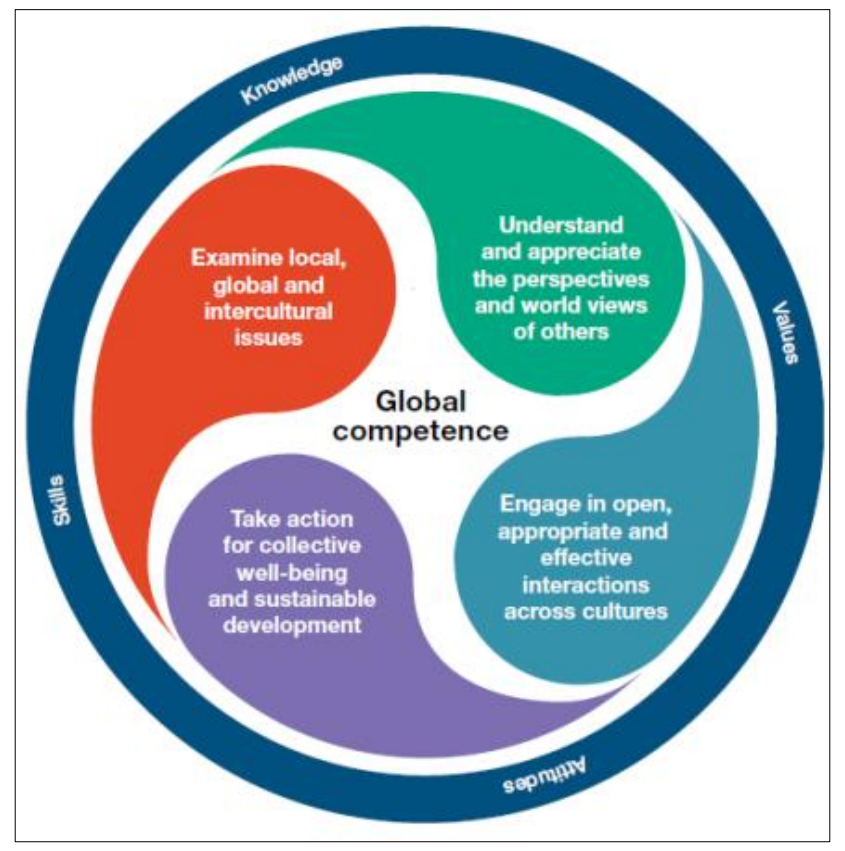

The OECD PISA framework emphasizes on the four dimensions of global competence which includes the inseparable knowledge, skills, attitudes and values. Colleges and universities play a big role in the development of global competence. Students should have the platform to develop these four dimensions. The curriculum, curricular activities, programs and extra-curricular activities help define the total skills set students acquire. According to NEA (2010), one element of global competence is international awareness 
which measures students' understanding of the world history, socio-economic and political systems. The understanding of the local and national events also has an international implications.

Another framework of global competence is developed by World Savvy referred to as the Global Competence Matrix. It was developed together with the Teachers College, Columbia University and the Asia Society. It contains the core concepts of global competence involving an interrelation of values and attitudes, behaviors and skills.

\section{Figure 2}

World Savvy's Global Competence Matrix

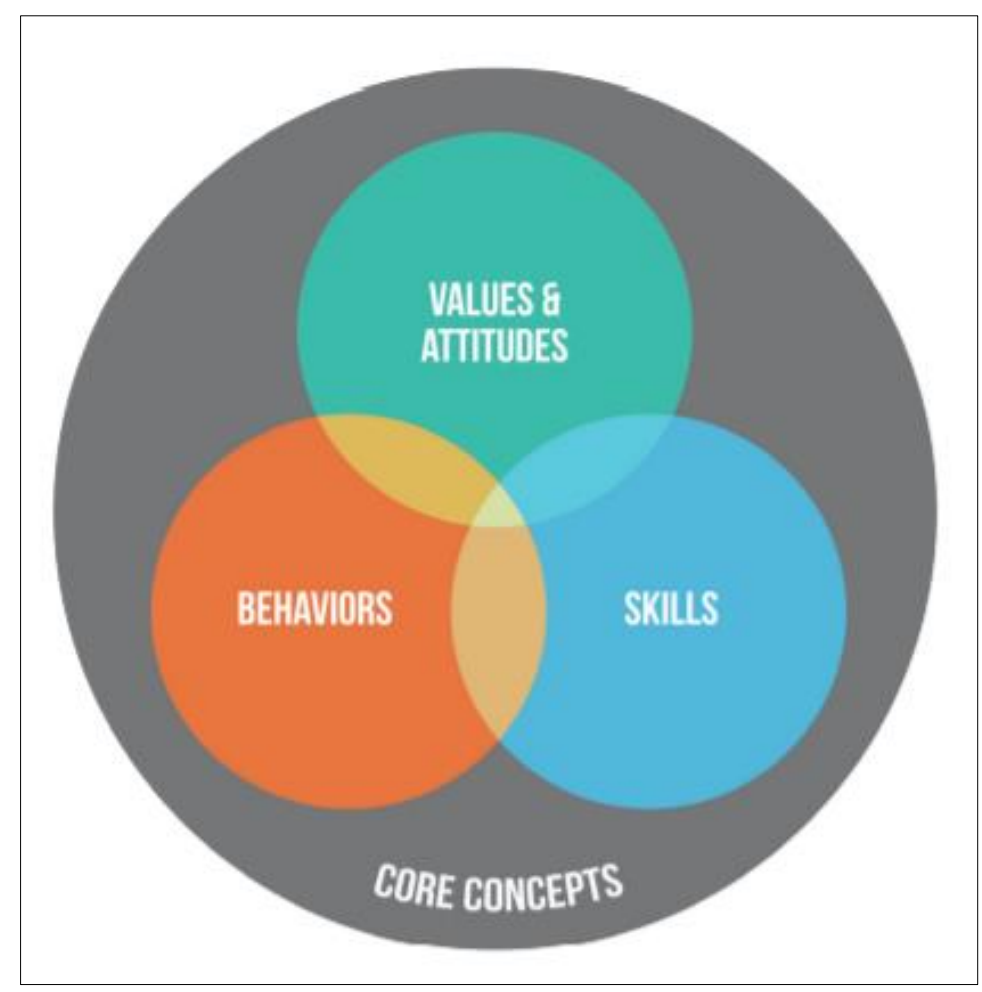

The core concepts emphasize that global competence is a journey and not an endpoint. The ongoing process of global competence development points to the different sets of expectations in order to be globally competitive. It enumerates the expected behaviors which mainly focus on problem-solving and decision making, forming opinion based on evidence, continuous learning, shared responsibility, shared knowledge, translating ideas to 
actions and collaborative thinking and problem-solving. Meanwhile, the values and attitudes include openness to new ideas, desire to engage with others, self-awareness, valuing perspectives, comfort with ambiguity, reflection on context and meaning, question prevailing assumptions, adaptability, empathy and humility. Lastly, the skills include scientific investigation, understanding of different perspectives, application of appropriate tools in communication and collaboration, listening and engaging in inclusive dialogue, fluent in digital technology, resiliency and critical thinking.

According to Salmon, Gangotena, \& Melliou (2018), "globally competent people are aware of world issues, take perspective, are engaged and know how to communicate to different people". Several authors suggest skills set necessary for the development of global competence. Fullan (2013) cites the most prominent 21st century competencies found in international frameworks include critical thinking, communication, collaboration, and creativity and innovation. The importance of critical thinking is emphasized by Drake (2014) which requires students to acquire, process, interpret, rationalize, and critically analyze conflicting points to arrive at a decision that calls for a concrete action. As a common $21^{\text {st }}$ century skill, communication refers not only to the ability to communicate effectively, orally, in writing, and with a variety of digital tools but also to listening skills. Meanwhile, collaboration enables working in teams and social networking skills whereas creativity is the pursuit of new ideas while innovation is the realization of the new idea (Fullan, 2013). Hixson, Ravitz \& Whisman (2012) identified eight important skills which also include critical thinking, collaboration, communication and creativity and innovation. Other important skills for them include self-direction skills, global connections, local connections and using technology as a learning tool. Whereas Spitzer, L. \& Cordero-Ramon, A. (2013) include a diverse and knowledgeable worldview, comprehends international dimensions of his/her major field of study, communicates effectively in another language and/or crossculturally, exhibits cross-cultural sensitivity and adaptability.

The OECD (2016) points to attitudes as the third dimension of the global competence. It consists of the four components: belief or opinion, emotion or feeling, evaluation as positive or negative and the tendency to behave in a particular way. To be globally competent, students need openness towards people from other cultures, respect for culture, global-mindedness and responsibility towards own actions. These attitudes are structured 
around values which refer to the general belief about the desirable goals. According to Oksal, \& Ekin (2013), students must have healthy attitudes and behaviors in relation to globalization and cultural diversity. In addition, Deardorff (2009) posits that intercultural competence requires attitudes of respect, openness and curiosity. Furthermore, Orozco-Domoe (2015) argues that the global inter-culturality requires internal attitudes for development. They should gain socio-linguistic knowledge, historical perspective and geographical awareness. Thus, teachers must provide learning experiences that shape students' attitudes towards globalization and cultural diversity.

According to Florez \& Jayaram (2016), the three countries surveyed in the Latin America and the Caribbean identified socioemotional skills as the main set of skills needed for employability. Other non-academic and non-technical skills identified by the employers include communication, teamwork, work ethic, relationship-building, decision-making, leadership, autonomy, responsibility, flexibility, adaptability, initiative, self-control, socialawareness, conflict-resolution, and self-esteem. Alongside knowledge and skills, Deardorff (2014) stresses that globally competent behaviour requires an attitude of openness towards people from other cultures or countries, respect for cultural otherness, global mindedness, and responsibility for one's own actions. Attitudes themselves can be structured around values.

Ark \& Liebtag (2017) note that new generation of students require different skills. For instance, the current Philippine workforce need more 'soft skills' (Pasion, 2017). This calls for the integration of the required skills in the curriculum. In the educational curriculum, the values education and MAPEH subjects in the primary and secondary levels include the development of soft skills. Educators need activities which develop socioemotional skills like team-based projects, apprenticeship programs, and vocational education. Furthermore, Billan (2014) suggests the three main teaching/learning strategies that support the development of global competence which include case studies, developing a business and/or marketing plan, and simulations and games. Depending on the program, study abroad and mandatory foreign language study are also helpful. 


\section{Methodology}

This study utilized descriptive method to describe the global characteristics of the students in terms of their global competencies, skills and attitudes. The participants were the 247 first year college students in the College of Business Administration comprising 88.2 percent of the total freshmen population. The survey was conducted during Second Semester of the Academic Year 2018 - 2019. Of the total college population of 280, 11.8 percent were absent during the survey administration.

\section{Table 1}

Percentage Distribution of the Respondent's Profile

\begin{tabular}{|c|c|c|}
\hline Profile Variables & Frequency & Percentage (\%) \\
\hline \multicolumn{3}{|l|}{ Age } \\
\hline 18 year old and below & 65 & 26.30 \\
\hline 19 years old & 149 & 60.30 \\
\hline 20 years old & 23 & 9.30 \\
\hline 21 years and above & 10 & 4.00 \\
\hline \multicolumn{3}{|l|}{ Sex } \\
\hline Male & 58 & 23.50 \\
\hline Female & 189 & 76.50 \\
\hline \multicolumn{3}{|l|}{ Program } \\
\hline Accountancy & 81 & 32.80 \\
\hline Business Administration & 107 & 43.30 \\
\hline Customs Administration & 59 & 23.90 \\
\hline
\end{tabular}

Table 1 summarizes the demographic profile of the respondents in terms of age, sex and program. Majority of the respondents are 19 year old $(60.3 \%)$ and female $(76.5 \%)$. As to program, majority are Business Administration (43.3\%) followed by Accountancy (32.8\%) and Customs Administration (23.9\%).

A self-constructed survey questionnaire was validated by the 12 faculty members prior to the writing of the final draft. The tool has three parts: 1) demographic profile of the respondents; 2) evaluation of the student's global competencies; and 3) assessment of the global skills and attitudes.

The author personally administered the data gathering through the approval from the Dean of the College of Business Administration. The objectives of the study were clearly discussed prior to the distribution of the tool. The students were given 20 minutes to answer the survey questionnaire and it was retrieved subsequently. The tallied data were treated with frequency count and percentage, weighted mean and t-test. 


\section{Findings and Discussion}

Table 2

Characteristics of Global Competencies

\begin{tabular}{|c|c|c|c|}
\hline Global Competencies & WM & VI & Rank \\
\hline I recognize and value cultural differences & 3.72 & Strongly Agree & 1 \\
\hline I am able to identify and appreciate different opinions & 3.61 & Strongly Agree & 2 \\
\hline $\begin{array}{l}\text { I know that another language helps to understand other } \\
\text { people and culture }\end{array}$ & 3.58 & Strongly Agree & 3 \\
\hline $\begin{array}{l}\text { I believe that through foreign language competency, } \\
\text { students get basic cross cultural communication by knowing } \\
\text { other countries and cultures }\end{array}$ & 3.55 & Strongly Agree & 4 \\
\hline I need to be internationally aware & 3.54 & Strongly Agree & 5 \\
\hline $\begin{array}{l}\text { I know that student should be proficient in the language of } \\
\text { specialized, general and cross-cultural communication } \\
\text { level }\end{array}$ & 3.53 & Strongly Agree & 6 \\
\hline I am aware of the growing interconnectivity of the world & 3.44 & Agree & 7 \\
\hline $\begin{array}{l}\text { I look for help to fulfill the need for international } \\
\text { understanding of my major field of study }\end{array}$ & 3.36 & Agree & 8 \\
\hline $\begin{array}{l}\text { I try to understand the international scope of my chosen } \\
\text { specialization }\end{array}$ & 3.32 & Agree & 9 \\
\hline $\begin{array}{l}\text { I am aware of the necessity of my ability to function within } \\
\text { this kind of connection of the world }\end{array}$ & 3.3 & Agree & 10 \\
\hline $\begin{array}{l}\text { I recognize that English is the world's dominant language, } \\
\text { but it may not always be }\end{array}$ & 3.28 & Agree & 11 \\
\hline I do general thinking for my overall worldview & 3.28 & Agree & 12 \\
\hline $\begin{array}{l}\text { I exhibit both cross-cultural sensitivity and adaptability } \\
\text { because I interact with different people }\end{array}$ & 3.21 & Agree & 13 \\
\hline I no longer look at the world through my opinion alone & 3.03 & Agree & 14 \\
\hline I familiarize myself with the host country's culture & 2.92 & Agree & 15 \\
\hline I question beliefs of other culture and challenges myself & 2.87 & Agree & 16 \\
\hline $\begin{array}{l}\text { I interact through membership in any internationally } \\
\text { oriented student organizations }\end{array}$ & 2.75 & Agree & 17 \\
\hline $\begin{array}{l}\text { I involve myself in the activities that bring together } \\
\text { international students }\end{array}$ & 2.74 & Agree & 18 \\
\hline $\begin{array}{l}\text { I participate in an overseas experience through study, } \\
\text { internship or work programs }\end{array}$ & 2.57 & Agree & 19 \\
\hline
\end{tabular}

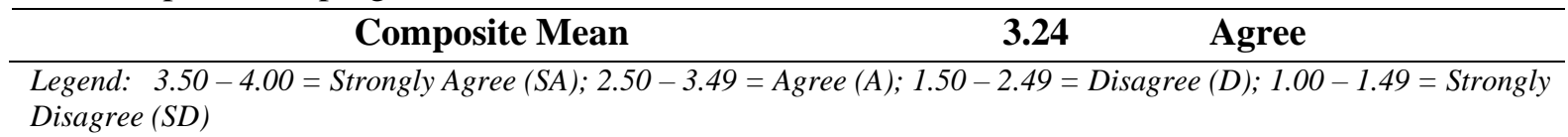


In Table 2, the respondents self-assessed their diverse knowledge on the different worldview, global understanding of his/her major field of study, effective communication in another language, cross cultural sensitivity and adaptability and global competencies throughout life. A composite mean of 3.24 showed the agreement on the global competencies. There were 19 items evaluated as important to develop and practice for global competence. Specifically, the students strongly agreed on recognizing and valuing cultural differences (3.72 weighted mean), ability to identify and appreciate different opinions (3.61 weighted mean), another language will help them understand other people and culture (3.58 weighted mean), believing that through foreign language competency, students get basic cross cultural communication by knowing other countries and culture ( 3.55 weighted mean) and the student's need to be internationally aware (3.54 weighted mean).

Primarily, the results indicated the respondents' strong agreement to the value of cultural differences. Through understanding other culture, they share respect while collaborating and share different opinions. The results conform to the study of Anbari (2014) that in order to achieve goals and avoid cultural misunderstandings, managers should be culturally sensitive and promote creativity and motivation through flexible leadership. In addition, significant findings focused on communication confirms Deardorff (2014) on global competence. These skills required that students need to communicate in more than one language, communicate appropriately and effectively with people from other cultures or countries, comprehend other people's thoughts, beliefs and feelings and see the world from their perspective and analyze and think critically in order to examine and evaluate relevant information.

In recognizing the value of cultural differences, most students are now trained on differing opinions enabling them accept and reject options. However, global issues require global mentality in a completely diverse paradigm. As Burnouf (2004) affirmed in the study that international awareness requires understanding global issues to become living and committed citizens in the ever changing global community.

The five least rated competencies belong to the cross cultural sensitivity and adaptability and how to carry global competencies throughout life. Students agree on participation in an overseas experience through study, internship or work programs (2.57 weighted mean), involving themselves in activities that bring together international students (2.74 weighted mean), interacting through membership in any internationally oriented 
students organizations ( 2.75 weighted mean), on questioning beliefs of other culture and challenges himself (2.87 weighted mean) and familiarizing themselves with the host country's culture (2.92 weighted mean).

Authors agree on the necessity to prepare students in a global perspective. This includes work preparation in different countries (MacCleoud, 2018) and sensitivity and adaptability to the cultures of different countries (Spitzer \& Cordero-Ramon, 2013). As supported by Jawabri (2017) that positive work environment, personal traits, and developed new skills have positive impact on internship experience, colleges and universities are more likely to engage in international internship programs. However, students still lack overseas experience through international internship and immersion. Programs such as international research presentation and participation in international student organization are still very limited.

Table 3

Extent of Global Skills that College Students Still Need to Improve

\begin{tabular}{|c|c|c|c|}
\hline Indicators & 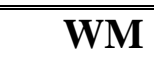 & VI & Rank \\
\hline Patience & 3.40 & To a Great Extent & 1 \\
\hline $\begin{array}{l}\text { Effective written and oral } \\
\text { communication }\end{array}$ & 3.35 & To a Great Extent & 2.5 \\
\hline $\begin{array}{l}\text { Assessing and analyzing } \\
\text { information }\end{array}$ & 3.35 & To a Great Extent & 2.5 \\
\hline Adaptability to different situation & 3.28 & To a Great Extent & 4 \\
\hline Entrepreneurship & 3.27 & To a Great Extent & 5 \\
\hline $\begin{array}{l}\text { Problem solving, critical thinking, } \\
\text { creative and comparative thinking } \\
\text { skills. }\end{array}$ & 3.26 & To a Great Extent & 6 \\
\hline $\begin{array}{l}\text { Able to formulate and manage } \\
\text { research works }\end{array}$ & 3.22 & To a Great Extent & 7 \\
\hline Leading by influence & 3.20 & To a Great Extent & 8 \\
\hline Collaboration across networks & 3.19 & To a Great Extent & 9 \\
\hline Composite Mean & 3.28 & To a Great Extent & \\
\hline
\end{tabular}

The respondents' self-evaluation on the extent of global skills that they still need to improve is shown in Table 3. The nine items were all rated to a great extent. The rankings of weighted means in descending order: patience (3.40); effective written and oral communication (3.35); assessing and analyzing information (3.35); adaptability to different situation (3.28); entrepreneurship (3.27); problem solving, critical thinking, creative and 
comparative thinking skills (3.26); ability to formulate and manage research work (3.22); leading by influence (3.20) and collaboration across the network (3.19). The composite mean of 3.28 interpreted as 'To a Great Extent' indicates that business students recognize the need to improve the nine global skills to be considered globally competent.

It is quite intriguing that students chose patience over other common skills such as communication and adaptability. It is obvious that developing global skills requires patience and openness. Similar to the study of Schnitker (2012) that patience facilitates goal pursuit in the face of obstacles. Students highly regard patience to all other attitudes in terms of development and achievement of goals. Innate to most of the Filipinos, the attitude of being 'matiisin' is highly reflected in the results.

The value of communications and assessing information is enormously common in most of the studies on workplace skills. For instance, Ranaut's (2018) note on internal and external communication in the workplace is the biggest challenge new workers need to face. At the students' level, exposure to internship and work placements are the best trainings. Similarly, access to social media and cyberspace allows students to get free information. However, assessing the value of the information gathered is again another challenge. With the proliferation of 'fake news' and unreliable internet sources, students are exposed to a pool of trash contents that only skilled and knowledgeable can filter.

The results, although all rated 'to a great extent', suggests that global skills are simply not as equally ranked as the other indispensable skills. Placing the value of collaboration across networks as well as leading by influence at the least suggest something on the 'employee mentality' of most, if not all, college graduates. The differing perception place on the priority and intention of the students after graduation.

The list of global attitude needing improvements is shown in Table 4. In a suggested list of 25, student-respondents chose multiple options tallied into frequency and percentage. The ten highly-rated global attitudes needing improvements include self-confidence $(73.28 \%)$, creativity $(60.73 \%)$, patience $(54.25 \%)$, flexibility $(53.04 \%)$, courage $(50.61 \%)$, interest in continuous learning $(44.53 \%)$, perseverance $(42.91 \%)$, resourcefulness $(42.51 \%)$, independence $(41.70 \%)$ and self-awareness $(39.68 \%)$. 
Table 4

Extent of Global Attitude that College Students Still Need to Improve

\begin{tabular}{lccc}
\hline \hline & Frequency & \% & Rank \\
\hline Self-confidence & 181 & 73.28 & 1 \\
Creativity & 150 & 60.73 & 2 \\
Patience & 134 & 54.25 & 3 \\
Flexibility & 131 & 53.04 & 4 \\
Courage & 125 & 50.61 & 5 \\
Interest in continuous learning & 110 & 44.53 & 6 \\
Perseverance & 106 & 42.91 & 7 \\
Resourcefulness & 105 & 42.51 & 8 \\
Independence & 103 & 41.70 & 9 \\
Self-awareness & 98 & 39.68 & 10 \\
Understanding & 97 & 39.27 & 11 \\
Self-knowledge & 95 & 38.46 & 12 \\
Initiative & 90 & 36.44 & 13 \\
Positive outlook toward diversity & 87 & 35.22 & 14 \\
Cultural sensitivity & 84 & 34.01 & 15 \\
Enthusiasm & 81 & 32.79 & 16.5 \\
Recognition of one's own cultural attitude & 81 & 32.79 & 16.5 \\
Sense of humor & 80 & 32.39 & 18 \\
Open-mindedness & 79 & 31.98 & 19 \\
Curiosity and inquisitiveness & 71 & 28.74 & 20 \\
Self-reliance & 69 & 27.94 & 21 \\
Assertiveness & 66 & 26.72 & 22 \\
Respect & 53 & 21.46 & 23 \\
Appreciation of diversity & 46 & 18.62 & 24 \\
Politeness & 39 & 15.79 & 25 \\
\hline
\end{tabular}

The students' regard to self-confidence directs to two possible things: the need to be globally competitive and its absence at the moment. It is relatively true that self-confidence gave one an advantage in the professional world. As Endratno (2018) proved that selfconfidence is highly significant to intentions. High self-esteem keeps them motivated to reach their intended goals. However, it is depressing that the ratings express an impending concern on students' low self-esteem as well. It is indeed reflective that students believe they need lose confidence and there is an immediate need to develop it more. Somehow, students lose sight of the global placement due to their low self-esteem. 
Table 5

Analysis of Difference on Global Competencies and Global Skills Needing Improvement according to Demographic Profile

\begin{tabular}{lcccccc}
\hline & \multicolumn{3}{c}{$\begin{array}{c}\text { Characteristics of Global } \\
\text { Competencies }\end{array}$} & \multicolumn{2}{c}{ Extent of Global Skills } \\
\cline { 2 - 7 } & F-value & p-value & I & F-value & p-value & I \\
\hline Age & 4.604 & 0.004 & S & 1.991 & 0.116 & NS \\
Sex & 1.053 & 0.294 & NS & 0.366 & 0.715 & NS \\
Program & 1.341 & 0.264 & NS & 0.038 & 0.962 & NS \\
\hline \hline
\end{tabular}

Legend: Significant at p-value $<0.05$

Table 5 shows the test of difference on the responses according to demographic profile. Using a t-test, the responses on the characteristic of global competencies and extent of global skills were tested according to the respondents' age, sex and program. Results mostly show no significant difference except for the characteristics of global competencies. When grouped according to age, it obtained p-value of 0.004 , less than 0.05 alpha level. The statistical difference suggests that the perception of the students on the global competencies differ as they age. As their responses differ significantly, the post hoc test further revealed that 21 years old and above have higher assessment on global competencies. As students' age, they develop more the global competencies they need including recognition of cultural differences and language development.

\section{Conclusion}

This study evaluated the global competencies, skills and attitudes of the business students in one of the private higher institution in Batangas City, Philippines. Particularly it assessed the students' manifestation of global competencies, determined the extent of global skills and attitudes that need improvement and tested the differences on the global competencies according to students' demographic profile. Through an exploratory research method, a set of 247 students in the College of Business Administration made a selfassessment in a researcher-made questionnaire. Data were analysed through frequency, percentage and t-test.

Based on the students' self-assessment, their global competencies include recognition of cultural differences, appreciation of different opinions and knowledge of the English 
language. However, they still need to improve their patience, analysis of information and effective written and oral communication. In addition, students point to self-confidence, creativity and patience as the global attitudes that they need to develop further. The perception of the students highly differ in terms of their age.

The data clearly show an alarming reality that higher education students are not yet globally competitive. The students' self-assessment highlights major deficiencies in the competencies, skills and attitudes. The very limited international exposure of the students affect their global paradigm. It is indeed necessary to educate them on a broad view of the world through exposure to international programs and activities such as student exchange, international immersion, collaborative research and organizations and global institutional partnerships. The students might have higher technical knowledge and know-how within the context of their specialization in a local perspective. It is indeed necessary that students think of a global perspective and a much broader set of competencies, skills and attitudes.

The author suggests a further scrutiny of the issue. As this is a self-assessment, the global competencies, skills and attitudes highly differ by location and educational institution. This could be done in several higher education institutions to further test the consistency of the results. The author also admits certain statistical limits and analysis. However, this exploratory study opens several related issues that need further assessment.

\section{References}

Anbari F., Khilkhanova E, Romanova M., Ruggia M., Tsay H. \& Umpleby S. (2009). Managing Cross Cultural Differences in Projects. PMI Global Congress North America 2009, pp. 1-11.

Ark, T. \& Liebtag, E. (2017). Educating for Global Competence: 6 Reasons, 7 Competencies, 8 Strategies, 9 Innovations. Gettingsmart.com. Available at: https://www.gettingsmart.com/2017/09/educating-for-global-competence-6-reasons-7competencies-8-strategies-9-innovations/ [Accessed 19 Oct. 2019].

Billan, R. (2014). Global Competence: Essential Characteristics As Perceived By Faculty And Program Heads In International Business Programs At Ontario's Five Institutes Of Technology And Advanced Learning. A Dissertation for the Program Doctor of Philosophy 2014. 
Boix-Mansilla, V., \& Jackson, A. (2011). Educating for global competence: Preparing our youth to engage the world. New York: Asia Society-Partnership for Global Learning CCSSO Ed-Steps.

Brunello, Giorgio; Wruuck, Patricia (2019). Skill Shortages and Skill Mismatch in Europe: A Review of the Literature. IZA Discussion Papers, No. 12346, Institute of Labor Economics (IZA), Bonn

Deardorff, D.K. (2014). Identification And Assessment Of Intercultural Competence As A Student Outcome Of Internationalization. Journal of Studies in International Education, 10 (3), 241-66.

Deardorff, D. K. (2009). The Sage handbook of intercultural competence. Thousand Oaks, Calif: Sage Publications

Drake, S.M. (2014). Designing Across The Curriculum For "Sustainable Wellbeing: A 21st Century Approach. In F. Deer, T. Falkenberg, B. McMillan, \& L. Sims (Eds.), Sustainable well-being: Concepts, issues, and educational practice (pp. 57-76). Winnipeg, MB: Education for Sustainable Well-Being (ESWB) Press.

Endratno, H. (2018), The Effect of Self-Confidence and Subjective Norm On students' Entrepreneurial Intention. Advances in Social Science, Education and Humanities Research, Volume 23, Number 1

Florez, A., Jayaram, S. (2016). Bridging the Skills Gap in Latin America and the Caribbean. FHI 360, R4D. Washington, D.C.

Fullan, M. (2013). Great To Excellent: Launching The Next Stage Of Ontario's Education Agenda. Toronto: Ontario Ministry of Education. Retrieved from: www.edu.gov.on.ca/eng/document/reports/FullanReport_EN_07.pdf. [Accessed 19 Oct. 2019]

Goodwin, B \& Hein, H. (2017). What Skills Do Students Really Need for a Global Economy? The Global-Ready Student, Volume 74, Number 4, pp 83-84

Igarashi,T., Acosta, P.A., Hamanaka, R.O. \& Rutkowski, J.J. (2017). Developing socioemotional skills for the Philippines' labor market (English). Directions in development; human development Washington, D.C.: World Bank Group. http://documents.worldbank.org/curated/en/333521498727263689/Developingsocioemotional-skills-for-the-Philippines-labor-market. [Accessed 19 Oct. 2019]

Jawabri, A. (2017). Exploration of Internship Experience and Satisfaction Leading to Better Career Prospects among Business Students in UAE. American Journal of Educational Research, 5(10), pp.1065-1079.

MacCleoud, H. (2018). Incorporating Intercultural and Global Competencies into Higher Education STEM Programming. ACS Symposium Series, pp.109-137. 
Moriba, S. \& Edwards, M.C. (2015). Examining the General Global Competence of Students Enrolled in an International Dimension Course: An Attempt to Internationalize Undergraduate Education in a College of Agriculture. Journal of Human Sciences and Extension Volume 3, Number 1

NEA. (2010). Global Competence Is a 21st Century Imperative. http://www.nea.org/assets/ docs/HE/PB28A_Global_Competence11.pdf . [Accessed 19 Oct. 2019]

OECD (Organisation for Economic Co-operation and Development) (n.d.) Beyond PISA 2015: A longer-term strategy of PISA. Online. www.oecd.org/pisa/pisaproducts/Longerterm-strategy-of-PISA.pdf]Accessed 19 Oct. 2019]

OECD (Organisation for Economic Co-operation and Development) (2016.) Global Competency for an Inclusive World. Online. http://globalcitizen.nctu.edu.tw/wpcontent/uploads/2016/12/2.-Global-competency-for-an-inclusive-world.pdf [Accessed 19 Oct. 2019]

Oksal, A., Ekin, M.T.Y. (2013). Student Teachers' Global Perspectives And Attitudes Towards Cultural Diversity: The Case Of Uludağ University. Procedia - Social and Behavioral Sciences 93 (2013) $597-601$

Orozco-Domoe, J.S. (2015). Journey to Global Competence: Learning Languages, Exploring Cultures, Transforming Lives. In: Learning Languages, Exlore Cultures, Transform Lives. Eds: Moeller, A.J. 2015 Central States Conference on the Teaching of Foreign Languages

Participate Learning (2017). What Do Globally Competent Students Look Like? Available online at https://www.participatelearning.com/blog/what-do-globally-competentstudents-look-like/. [Accessed 19 Oct. 2019]

Pasion, P. (2017). Workers With Good Behavioral Skills Get Better Pay - Study. Rappler. Available online at: https://rappler.com/business/workers-behavioral-skills-better-payworld-bank-study. [Accessed 19 Oct. 2019]

Ranaut, B. (2018). Importance of Good Business Writing Skills. International Journal of Language and Linguistics, 5(2), pp.32-40.

Salmon, A.K., Gangotena, M.V. \& Melliou, K. Becoming Globally Competent Citizens: A Learning Journey of Two Classrooms in an Interconnected World. Early Childhood Educ J 46, 301-312 (2018). https://doi.org/10.1007/s10643-017-0860-z

Schnitker, S.A. (2012). An Examination Of Patience And Well-Being. The Journal of Positive Psychology, 7:4, 263-280, DOI: 10.1080/17439760.2012.697185 
Sparks, S. D. (2015). U.S. Millennials Come Up Short in Global Skills Study Shortfalls affect all segments of American society. Education Week. Available at: https://www.edweek.org/ew/articles/2015/02/18/us-millennials-come-up-short-inglobal.html. [Accessed 19 Oct. 2019]

Spitzer, L. \& Cordero-Ramon, A. (2013). Language Study: A Necessary Part of the Internationalized Curriculum. Multicultural Learning and Teaching, Volume 8: Issue 1. DOI: https://doi.org/10.1515/mlt-2012-0038

Tindowen, D.J.C., Bassig, J.M. \& Cagurangan, J. (2017). Twenty-First-Century Skills of Alternative Learning System Learners. SAGE Open, July-September 2017: 1-8. DOI: $10.1177 / 2158244017726116$

World Savvy (n.d.). World Savvy's Global Competence Matrix. Available online at: https://www.worldsavvy.org/our-approach/global-competence/. [Accessed 19 Oct. 2019] 